\title{
On Ways and Importance of Integrating Education with "Love" into Current College Students' Ideological and Political Education
}

\author{
Haiping Zheng and Desheng Zeng * \\ Jingdezhen Ceramic Institute, Jingdezhen, Jiangxi 333403, China \\ * The Corresponding author
}

Keywords: Education with "love"; The contemporary college students; Ideological and political education

\begin{abstract}
In recent years, the various problems in the the college students' ideological and political education become highlighted gradually. From the prospective of the education with "love", this article mainly focuses on discussing the purpose, goal, principle, content, degree and way of college students' ideological and political education in order to promote the common development of the contemporary college students' awareness of "love" and ideological and political education, strengthen and consolidate the position and function of the education with "love" in college students' ideological and political education and develop the advanced talents fully developed in morality, intelligence, physique and aesthetics for socialist modernization drive.
\end{abstract}

\section{Introduction}

With the expansion of university enrollment, the number of college students increases constantly, but the various problems in the college students' ideological and political education also become highlighted gradually. This article makes exploration and research from the prospective of integrating the education with "love" into college students' ideological and political education, and mainly focuses on the purpose, goal, principle, content, degree and way of integrating the education with "love" into college students' ideological and political education in order to promote the common development of the contemporary college students' ideological and political education and professional education, strengthen and consolidate the position and function of the education with "love" in college students' ideological and political education and develop the advanced talents fully developed in morality, intelligence, physique and aesthetics for socialist modernization drive.

\section{Gradually Highlighted Various Problems in Current College Students' Ideological and Political Education}

The Gradually Highlighted Various Problems in Current College Students' Ideological and Political Education Which are Mainly Embodied in the Following Aspects. Firstly, the political theoretical level is not high. most of students lack the learning awareness of political theory and the understanding and mastering of fundamental policy. Secondly, the mental motivation is not correct. The mental motivations of college students have become more complicated, and which show certain utility and vanity. Some students' purposes are being a civil servant or a member of public institutions and state-owned enterprises, some students' purposes are just meeting their own vanity for competition with others. The exemplary vanguard role of party members is not prominent. The performance of some students after joining the party is very different from the performance before joining the party, some party members are relax to their own requests after joining the party, their service and dedication awareness become faded, and their work enthusiasm become weakened. Thirdly, there is no strong sense of organization and sense of discipline, and there is a decline in participation enthusiasm. It occurs from time to time some students are late or absent by who the freedom is emphasized too much.

The Education with "love" is not Fully Integrated into the Current Ideological and Political Education in Colleges and Universities. After seriously understanding and investigating the 
contemporary college students' ideological and political education, it is found that the education with "love" is not fully integrated into the current ideological and political education in colleges and universities. The education with "love" and the students' ideological and political education are separated, and there is less association between them that are mainly embodied in the following aspects. Firstly, there are a few materials with "love" in the content of the textbook. Secondly, there are a few materials with "love" in the content of preparing lessons and classroom demonstration of many art teachers of the current colleges. Thirdly, there are a few materials with "love" is involved in the assignment given in art education of the current colleges. Fourthly, there are a few materials with "love" is involved in the artistic creation and the social practice of the current higher education. The few materials with "love" is not the result of teachers' intentional acts, and is not the result caused by the students. The materials with "love" is ignored in the teaching materials, teaching ideas and teaching ways of the current higher education. The lack of materials with "love" is an unconscious gap or the blind-spot of higher education. For the students taught in this way, it seemed to be very difficult to actively love others and correctly love themselves in life, study and work. They even fell strange when red materials and party spirit theme are mentioned.

\section{Importance of Integrating Education with "Love" into College Students' Ideological and Political Education}

Integrating education with "love" into college students' ideological and political education will help strengthens the party spirit education of the contemporary college students, makes college students know more about the national conditions, the national history, the status of the party and the party's history, arise the college students' love for the party, the state and Chinese nation, promote the college students to carry out in-depth understanding and knowledge of Marxism-Leninism, Mao Zedong thought, Deng Xiao-ping theory, the important thought of three represents and the concept of scientific development and make the college students' great faith of insisting in following the party and taking the socialist road become more firm.

It is an active, creative and practical exploration and research of the ideological and political education and professional education of the colleges students to integrate loving country, loving home, loving study, loving work, loving oneself, understanding national conditions and knowing national history into the professional education and its forms of the contemporary college students which help promote the connotation and extension of colleges' ideological and political education, party spirit education and education and teaching reform.

It is conductive to the promotion of the inheritance and development of the education with "love" to carry out this research. It will greatly enrich the ways and means of the educational practice of college students to integrate various subject education with "love" and subject activities with "love" into colleges' ideological and political education.

The involving of materials with "love" in the preparation of lessons and teaching of professional teachers can help enhance the self-cultivation of professional teachers, enhance the professional teachers' sense of responsibility and mission of carrying out ideological and political education and change the relatively single situation of college students' ideological and political education work that the work of college students' ideological and political education is just carried out by the double-course teachers, the party and government cadres, counselors and the class teachers in order to gradually form the new situation of college students' ideological and political education that the concerted efforts are made by professional teachers, the ideological and political teachers, the party and government cadres, counselors and the class teachers.

\section{How to Integrate Education with "Love" into College Students' Ideological and Political Education}

It needs a comprehensive and in-depth research on the purpose, goal, principle, content and ways of integrating how to integrate education with "love" into college students' ideological and political education and how to carry out the common development of the education with "love", ideological 
and political education and professional education.

The purpose of integrating the education with "love" into the college students" ideological and political education and professional education is enhancing and consolidating the position and function of colleges' ideological and political education and developing the advanced talents fully developed in morality, intelligence, physique and aesthetics for socialist modernization drive.

The three goals of integrating the education with "love" into the party spirit education and the professional education of college students are improving and innovating the ways and means of the party spirit education of college students, promoting the common development of the party spirit education, the professional education and the education with "love" of college students and promoting the inheritance and development of "love".

The following four aspects are the principles and degree of integrating the education with "love" into college students' ideological and political education. Firstly, the elements of "love" should be integrated into the professional education. The materials with "love" should be integrated into many aspects of professional education such as compiling textbook, teaching process, classroom demonstration, homework assignment and site selection. Secondly, the degree and content of integrating should be appropriate. The materials with "love" integrated should not too much. The students should be subtly guided step by step to enhance the awareness and ability of loving country, loving people, loving study, loving work, loving others and loving themselves and expand their horizons of "love". Thirdly, other perspectives should not be abandoned because of "love" which should be coexisted with "love" for common education and common development. The purposes of integrating the materials with "love" are adding content and perspectives and carrying out coexistence, common education and common development. In a word, the purpose of integrating the materials with "love" is enhancing the art college students' understanding, experience and practice of "love" on the basis of the cultivation of college art students. Fourthly, the materials with "love" involved in the professional teaching should be seriously taught, explained and applied. After the integration of the materials with "love", the professional teachers should seriously teach and explain the subject with "love" and properly give homework of the materials with "love". They should not be blind to the materials with "love" to which more attention should be paid.

For the content of Integrating Education With "Love" into College Students" Ideological and Political Education, on the basis of being in accordance with integrating principle, some materials with great love are selected as the integrating content. All kinds of art forms and content can be involved in the integrating content such as sketch, drawing, traditional Chinese paintings, pastel, oil painting, ceramics, calligraphy, painting and calligraphy, music, sculpture, photography, animation, cartoon and architecture.

Ways of integrating education with "love" into college students' ideological and political education. Firstly, the content and thought with "love" shall be added and emphasized in the talents training objective and the syllabus in order to unify teaching ideas and change the teachers' ideas in teaching. Secondly, the materials with "love" shall be added to the textbook contents of colleges' art professional courses, or the textbook contents of colleges' art professional courses shall be displaced by the materials with "love". Thirdly, the materials with "love" shall be embodied in the contents of preparing lessons and classroom demonstration of works. For promoting the students to gain more contacts with the materials with "love" and have more through, vivid, deep and unforgettable understanding of the materials with "love", on the basis of insisting on the integrating principle, the teachers themselves should involve and understand more materials with "love", in addition, they should also create more artistic works with "love", properly present the examples with "love" in the contents of preparing lessons and properly show the artistic works with "love" in the classroom demonstration. Fourthly, the materials with "love" shall be involved in the students' assignments given in colleges' ideological and political education. the success of college students in study needs assiduous practice. On the one hand, the purpose of carrying out professional skills training and promotion is achieved. On the other hand, the students shall be more familiar with the materials with "love", and they shall have more deep, vivid and unforgettable understanding of the materials with "love", more abundant and deep comprehension of revolution and enhanced effects 
of ideological and political education. Fifthly, in the case of having same professional thought and direction, the revolutionary memorial spots and revolutionary scenic spots with dense "revolutionary" atmosphere shall be mainly selected when the practice base of sketch of the college art professional education is needed to be selected. The sketch and capturing scenery in revolutionary scenic spots with dense "revolutionary" atmosphere can help the students realize the value and significance of creation as if they are in the times of revolution, understand the deep connotation of loving country more deeply, restudy the great revolutionary history, enhance the feelings of loving country and home and enhance the enthusiasm of loving the party and our country. Sixth, the art forms with "love" as the subject shall be frequently adopted to carry out party branch activities or professional competitions. The competition activity of artistic creation with commemorations of founding the party, founding the army, founding the state and victory in the war of resistance as subject is a good example. In addition, the artistic works of the teachers and the students shall be frequently exhibited in order to not only enrich the forms and contents of party branch activities and professional competitions but also enhance the consciousness of party spirit of student party members.

\section{Conclusion}

It is believed that integrating the materials with "love", the art with "love" and the idea with "love" into ideological and political education in colleges and universities must promote the common development of red education, the education of party spirit of students and professional education, strengthen and consolidate the position and function of college students' ideological and political education and develop numerous advanced talents fully developed in morality, intelligence, physique and aesthetics for socialist modernization drive.

\section{Reference}

[1] Yan Liu, Jing Chen, Yafen Wu, Pingsheng Zhou, Fan Yang. Research on the Function and Application of Red Art in the Party Spirit Education of College Student Party Members[J]. Human Resource Management, 2015, (5).

[2] Mincheng Huang. Ideological and Political Education and Quality Education in Colleges and Universities[J]. Scientific Socialism, 2004, (2)61-62.

[3] Zhuanghai Shen. Thought of Promoting the Discipline Construction of Ideological and Political Education[J]. New Moral Education . Ideological and Political Education, 2006, (6):33-36.

[4] Huifeng Li. Good Work of College Students' Ideological and Political Education Under New Situation[J]. Forward Position, 2004, (7):122-124.

[5] Meijuan Dong. Though of Re-education of Art Students Party Members in College and University Under New Situation. "The Guide of Science \& Education <Early>”, 2010, (11).

[6] Jianming Zhang. Discussion on the Situation and Training Methods of Student Party Members' Quality in College and Universities Under New Situation[J]. Journal of Liaoning Academy of Governance, 2009, (12). 